\title{
Differential effects of HIF2a antagonist and HIF2a silencing in renal cancer and sensitivity to repurposed drugs
}

\author{
Esther Arnaiz ${ }^{1}$, Ana Miar ${ }^{2 *}$, Esther Bridges ${ }^{1}$, Naveen Prasad ${ }^{2}$, Stephanie B. Hatch ${ }^{3}$, Daniel Ebner ${ }^{3}$,
} Charles H. Lawrie ${ }^{4 \dagger}$ and Adrian L. Harris ${ }^{1+}$

\begin{abstract}
Background: In clear cell renal cell carcinoma, $80 \%$ of cases have biallelic inactivation of the VHL gene, leading to constitutive activation of both HIF1a and HIF2a. As HIF2a is the driver of the disease promoting tumour growth and metastasis, drugs targeting HIF2a have been developed. However, resistance is common, therefore new therapies are needed.

Methods: We assessed the effect of the HIF2a antagonist PT2385 in several steps of tumour development and performed RNAseq to identify genes differentially expressed upon treatment. A drug screening was used to identify drugs with antiproliferative effects on VHL-mutated HIF2a-expressing cells and could increase effectiveness of PT2385.

Results: PT2385 did not reduce cell proliferation or clonogenicity but, in contrast to the genetic silencing of HIF2a, it reduced in vitro cell invasion. Many HIF-inducible genes were down-regulated upon PT2385 treatment, whereas some genes involved in cell migration or extracellular matrix were up-regulated. HIF2a was associated with resistance to statins, addition to PT2385 did not increase the sensitivity. Conclusions: this study shows key differences between inhibiting a target versus knockdown, which are potentially targetable.
\end{abstract}

Keywords: HIF2a, Renal cancer, EMT, Drug resistance

\section{Background}

Renal cell carcinoma (RCC) is amongst the 10 most common cancers [1]. The most common subtype of RCC is clear cell RCC (ccRCC, 70-85\% of cases), characterised by high vascularity and showing lipid and glycogen accumulation in the cytoplasm [2]. Most ccRCC cases present biallelic inactivation of the von Hippel Lindau $(V H L)$ tumour suppressor gene. Under normal oxygen conditions, VHL polyubiquitinates hypoxia-inducible factor 1 alpha (HIF1 $\alpha)$ and 2 alpha

\footnotetext{
* Correspondence: anbelen_mc@hotmail.com

${ }^{\dagger}$ Charles H. Lawrie and Adrian L. Harris contributed equally to this work.

${ }^{2}$ Department of Oncology, Old Road Campus Research Building, University of Oxford, Oxford OX3 7DQ, UK

Full list of author information is available at the end of the article
}

(HIF2 $\alpha$ ) targeting them for proteasomal degradation, but in the absence of VHL, HIF $\alpha$ subunits can translocate to the nucleus, dimerize with HIF1 $\beta$ and transactivate the expression of their downstream genes [3]. Both HIF1 $\alpha$ and HIF $2 \alpha$ appear to be involved in ccRCC initiation, however, they have contrasting roles as the disease develops [4]. In contrast to other cancers, in ccRCC HIF1 $\alpha$ functions as a tumour suppressor by attenuating tumour cell growth, whereas HIF2 $\alpha$ promotes tumour development $[4,5]$. This is partially achieved by the opposing effects on the oncogene MYC, with HIF2 $\alpha$ enhancing MYC activity and the consequent alteration in the DNA methylation patterns, whereas HIF1 $\alpha$ impairs MYC activity $[6,7]$. Additionally, HIF pathway deregulation due

(c) The Author(s). 2021 Open Access This article is licensed under a Creative Commons Attribution 4.0 International License, which permits use, sharing, adaptation, distribution and reproduction in any medium or format, as long as you give appropriate credit to the original author(s) and the source, provide a link to the Creative Commons licence, and indicate if changes were made. The images or other third party material in this article are included in the article's Creative Commons licence, unless indicated otherwise in a credit line to the material. If material is not included in the article's Creative Commons licence and your intended use is not permitted by statutory regulation or exceeds the permitted use, you will need to obtain permission directly from the copyright holder. To view a copy of this licence, visit http://creativecommons.org/licenses/by/4.0/. The Creative Commons Public Domain Dedication waiver (http://creativecommons.org/publicdomain/zero/1.0/) applies to the data made available in this article, unless otherwise stated in a credit line to the data. 
to VHL mutation leads to ccRCC angiogenesis, and therefore, to the characteristic high vasculature of this tumour type [8]. Similarly, HIFs regulate every step of the metastatic process: from cell acquisition of motile and invasive phenotype (epithelial to mesenchymal transition, EMT), to inhibition of anoikis and later establishment of the premetastatic site prior to clonal expansion $[9,10]$. Epigenetic alterations such as DNA methylation can regulate HIF $2 \alpha$-induced expression of metastatic genes in ccRCC [11], and superenhancer formation in inflammatory ccRCC cells promotes neutrophildependent lung metastasis [12]. Overall, HIF $2 \alpha$ promotes metastasis in RCC [13, 14], and high HIF $2 \alpha$ mRNA and protein levels in tumour tissue is associated with shorter survival [15].

Due to HIF $2 \alpha$ involvement in ccRCC progression, drugs targeting HIF $2 \alpha$ have recently been developed. Scheuermann et al. showed that smallmolecule ligands such as PT2385, PT2399 and PT2977 can bind to a large hydrophobic cavity in the PAS-B domain of HIF $2 \alpha$, induce a conformational change, avoid the heterodimerization with HIF1 $\beta$ and finally impair the activation of downstream target gene expression [16-18]. PT2385 treatment inhibited the expression of HIF $2 \alpha$ target genes in ccRCC cell lines and tumour xenografts and it promoted tumour regression faster than sunitinib [19], as did PT2399 [20]. In addition, PT2399 was demonstrated to reduce lung metastasis in animal models in vivo [21]. A phase I trial in previously treated patients showed that PT2385 was well tolerated and had a favourable safety profile, as no dose-limiting toxicities were observed at any dose level tested [22]. However, evaluation of the pharmacokinetic profiles of PT2385 showed that a significant proportion of patients were underexposed. These results promoted the development of the second-generation HIF $2 \alpha$ antagonist PT2977 with the aim of improving PT2385's variable and dose-limited pharmacokinetics resulting from extensive metabolism of PT2385 to its glucuronide metabolite [23].

Nevertheless, long term exposure to these HIF2 $\alpha$ inhibitors generates resistance via mutations in the HIF $2 \alpha$ binding pocket or in the heterodimerization partner HIF1 $\beta[20,24]$. Therefore, it is necessary to use a different approach to discover drugs against this malignancy. Statins (small-molecule inhibitors of the 3-hydroxy-3methyl-glutaryl-coenzyme A (HMG-CoA) reductase (HMGR), the rate limiting enzyme of the mevalonate pathway) are reported to be differentially toxic for VHLdefective ccRCC cell lines [25], suggesting that repurposing well-known and well-characterized drugs could provide a novel therapeutic strategy to target ccRCC combined with PT2385, as statins have long been used to reduce cholesterol levels [26].

We investigated the effects of PT2385 in ccRCC by analysing migration, invasion, the clonogenic potential and the alteration in gene expression. In addition, we evaluated the effect of the drugs in the Pharmakon 1600 library to identify currently used or approved drugs with possible additive effects in the treatment of ccRCC.

\section{Methods}

\section{Cell culture and cell transfection}

Both 786-0 cells (obtained from the American Type Culture Collection (ATCC), CRL-1932 $2^{\mathrm{rm}}$ ) and RCC4 cells, gift from W. Kaelin [27], were cultured in DMEM low glucose medium $(1 \mathrm{~g} / \mathrm{L})$ supplemented with $10 \%$ FBS no longer than 20 passages. They were mycoplasma tested every 3 months and all of them were authenticated using DNA STR analysis. 786-0 wild type (786-0 WT) cell line is $V H L$ defective and contains an inactivating mutation in HIF1 $\alpha$ gene, leading to constitutive expression of HIF2 $\alpha$. RCC4 VHL mutant cell line stably expressing an empty vector (RCC4 WT) or a vector for VHL overexpression (RCC4 VHL) were used (Table 1).

Transfection of HIF $2 \alpha$ siRNA $(\operatorname{siHIF} 2 \alpha)$ and siRNA control (siCON) (Supplementary Table 1) was performed with 12,000 cells using Optimem reduced serum medium at a final concentration of $20 \mathrm{nM}$. Oligofectamine (12252-011, Thermo Fisher) was used following the manufacturer's instructions.

\section{Western blot}

Cells were washed with cold PBS and lysed 30 min on ice with RIPA lysis buffer (R0278, Sigma) containing protease (cOmplete, 11697498001, Roche) and phosphatase (phosSTOP, 4906845001, Sigma) inhibitor cocktails. Lysates were cleared by centrifugation and supernatants were boiled at $95^{\circ} \mathrm{C}$ for $5 \mathrm{~min}$ in $4 \mathrm{x}$ NuPAGE LDS sample buffer (NP0007, Invitrogen) containing $10 \% \beta$-mercaptoethanol. Samples were run on NuPAGE Novex 4-12\% Bis-TRIS gels (NP0336BOX, Invitrogen) using NuPAGE MOPS-SDS running buffer (NP000102, Invitrogen) and afterwards, proteins were transferred to PVDF membranes (IPVH00010, Millipore). Membranes were blocked with 5\% milk (A0830, Applichem) in TBS-T (TBS containing 0.1\% Tween-20) for $1 \mathrm{~h}$ at room temperature and were then incubated overnight with anti-HIF $2 \alpha$ primary antibody (NB100122, Novus Biologicals) or $\beta$-actin peroxidase (A3854, Sigma) in $5 \%$ milk TBS-T at $4{ }^{\circ} \mathrm{C}$. Membranes were washed $3 \mathrm{x}$ in TBS-T and incubated with HRP-antirabbit secondary antibody (P0448, Agilent). Development was performed with Amersham ECL Prime Western Blotting Detection Reagent (GERPN2232, Sigma) using ImageQuant $^{\mathrm{TM}}$ LAS 4000. 
Table 1 Cell lines

\begin{tabular}{lllll}
\hline Cell line & VHL expression & HIF1a expression & HIF2a expression & Genetic modification \\
\hline $786-0$ WT & - & - & + & - \\
RCC4 WT & - & + & + & - \\
RCC4 VHL & + & - & - & VHL overexpression \\
$786-0$ siCON & - & - & + & siRNA control \\
$786-0$ siHIF2 $a$ & - & - & - & siRNA for HIF2a \\
\hline
\end{tabular}

\section{RT-qPCR}

RNA was extracted using the Tri-Reagent protocol (T9424, Sigma) and $1 \mu$ g of RNA was reverse transcribed into cDNA with the High Capacity cDNA reverse transcription kit (44368813, Thermo Fisher) using random hexamer primers. The PCR reaction containing SensiMix $^{\text {TM }}$ SYBR Green ${ }^{\circledR}$ No-ROX Kit (QT650-20, Bioline) was run on a 7900 Real time PCR System with standard cycling conditions: $10 \mathrm{~min} 95^{\circ} \mathrm{C}$, and 40 cycles of $15 \mathrm{~s}$ $95^{\circ} \mathrm{C}$ followed by $1 \mathrm{~min} 60^{\circ} \mathrm{C}$. Gene expression was analysed with the $\mathrm{Ct}$ method using HPRT1 expression for normalization [28]. The primers used are listed in Supplementary Table 2 .

\section{Migration assay}

$1.2 \times 10^{4} 786-0$ cells or $2 \times 10^{4}$ RCC4 cells were seeded per well in 96-well ImageLock ${ }^{\mathrm{Tm}}$ plates $(4379$, Essen BioScience) and incubated for $24 \mathrm{~h}$. When the effect of PT2385 (B1920, BioVision) was tested, the compound was added to the wells once the cells were attached. After wounding, cells were washed with fresh media and plates were placed into the IncuCyte $\mathrm{ZOOM}^{\odot}$ until wound closure. Scanning was performed using a $10 \mathrm{x}$ objective and scheduled every $2 \mathrm{~h}$. Migration ability of the cells was analysed through two integrated metrics that the IncuCyte ${ }^{\mathrm{TM}}$ Software calculates based on the processed images: wound width and wound confluence. Wound width represents the average distance $(\mu \mathrm{m})$ between the leading edge of the population of migrating cells (scratch wound mask) within an image. Wound confluence determines the percentage of wound area that is occupied by cells, and it relies on the initial scratch wound mask to differentiate the wounded from the non-wounded region.

\section{Invasion assay}

96-well ImageLock ${ }^{\mathrm{TM}}$ plate wells were coated with a thin layer of Matrigel $^{\odot}$ Growth Factor Reduced Basement Membrane Matrix (354,230, Corning) and the plate was placed in a $37^{\circ} \mathrm{C}$ incubator, $5 \% \mathrm{CO}_{2}$ overnight. Matrigel ${ }^{\odot}$ was removed and $1.2 \times 10^{4} 786-0$ cells or $2 \times 10^{4}$ RCC4 cells were seeded per well and incubated for $24 \mathrm{~h}$. PT2385 was added once the cells were attached. After performing the wound and washing the wells, $50 \mu \mathrm{L}$ Matrigel $^{\ominus}(8 \mathrm{mg} / \mathrm{mL})$ was added and the plate was placed in the incubator for $30 \mathrm{~min}$. After this time, $100 \mu \mathrm{L}$ cell culture media (containing PT2385 in the corresponding experiment) was added to each well. The plate was then placed into the IncuCyte $\mathrm{ZOOM}^{\circledR}$ for 5 days. Scanning was performed using a $10 \mathrm{x}$ objective and scheduled every $4 \mathrm{~h}$. The invasion ability of the cells was analysed using the relative wound density (RWD), which represents the density of the wound region relative to the density of the cell region, relying on the initial scratch wound mask to differentiate between cell-occupied and cell-free regions of the image.

\section{Cell proliferation assay}

To validate the screening hits, simvastatin (S6196, Sigma), fluvastatin sodium hydrate (SML0038, Sigma) and terbinafine hydrochloride (T8826, Sigma) were added to the cell culture and cell viability was analysed 5 days later using CyQUANT ${ }^{\mathrm{Tm}}$ Cell Proliferation Assay (C7026, Invitrogen) as per manufacturer's instructions.

CyQUANT $^{\text {тм }}$ Cell Proliferation Assay was also used to determine cell proliferation after PT2385 treatment.

\section{Colony formation assay}

1000 cells were plated in $100 \mathrm{~mm}$ plates in $20 \mathrm{~mL}$ media and cultured for 10 days. Media was removed and Coomassie blue solution $\left(\mathrm{H}_{2} \mathrm{O}\right.$ containing $50 \%$ methanol, $7 \%$ acetic acid glacial (A/0360/PB17, Thermo Fisher) and 0.1\% Brilliant Blue R (B7920, Sigma)) was added to fix and stain the colonies for $2 \mathrm{~h}$. Then, Coomassie blue solution was recovered and plates were washed with tap water and allowed to dry overnight. Plates were scanned using UMAX MagicScan software. Colony count was manually performed using Fiji Image J Software.

\section{RNA sequencing (RNAseq)}

The sequencing reads were checked for their quality using FastQC and low quality reads were trimmed using cutadapt. The trimmed reads were aligned to the human genome using STAR. Number of reads per gene (gene counts) was calculated using featureCount. Human assembly release GRCh38 was used for alignment and gene counting.

Differentially expressed genes (padj cut off $<0.05$ ) and enriched gene ontological terms on biological processes or cellular components between 786-0 WT and 786-0 
A
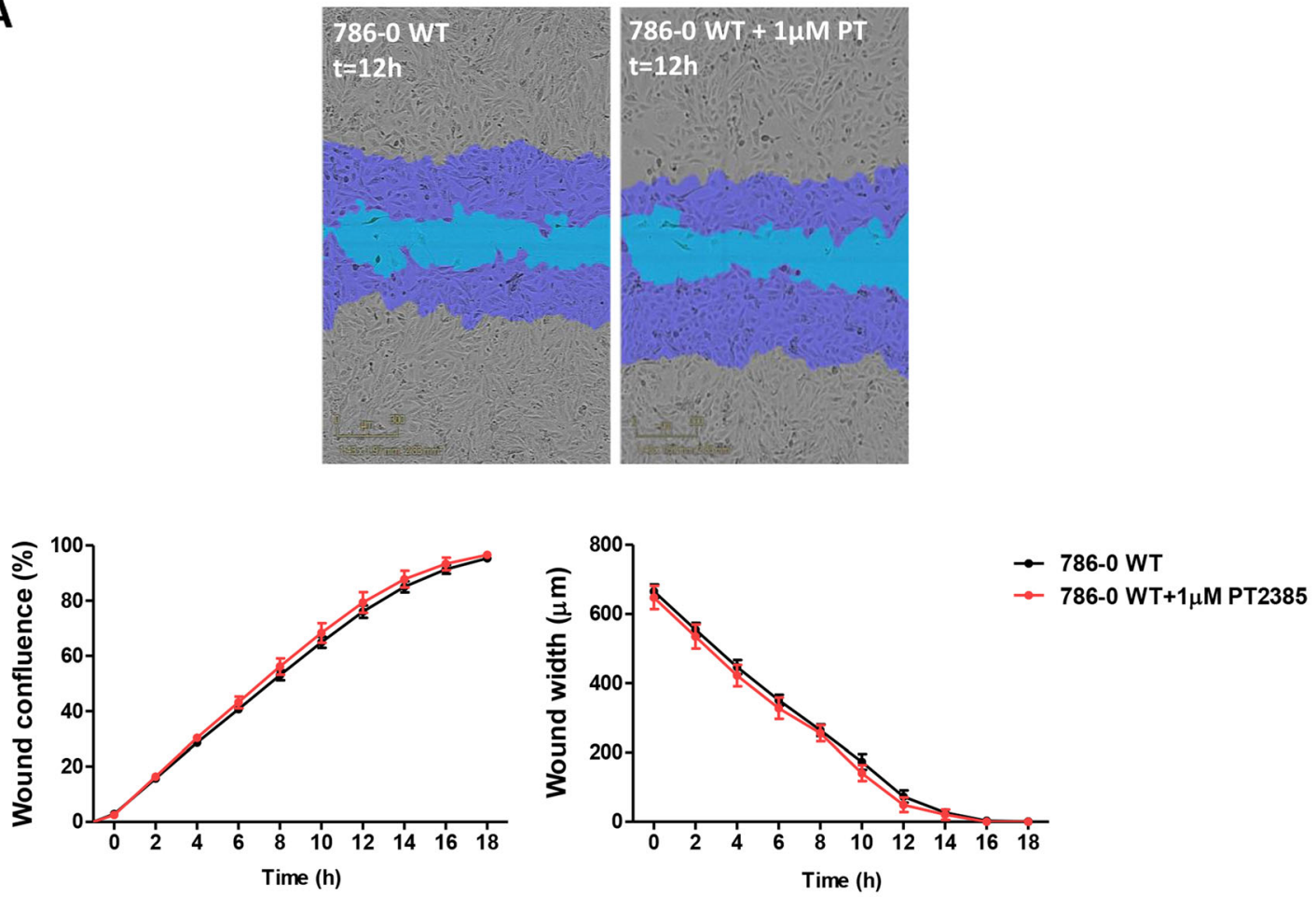

B
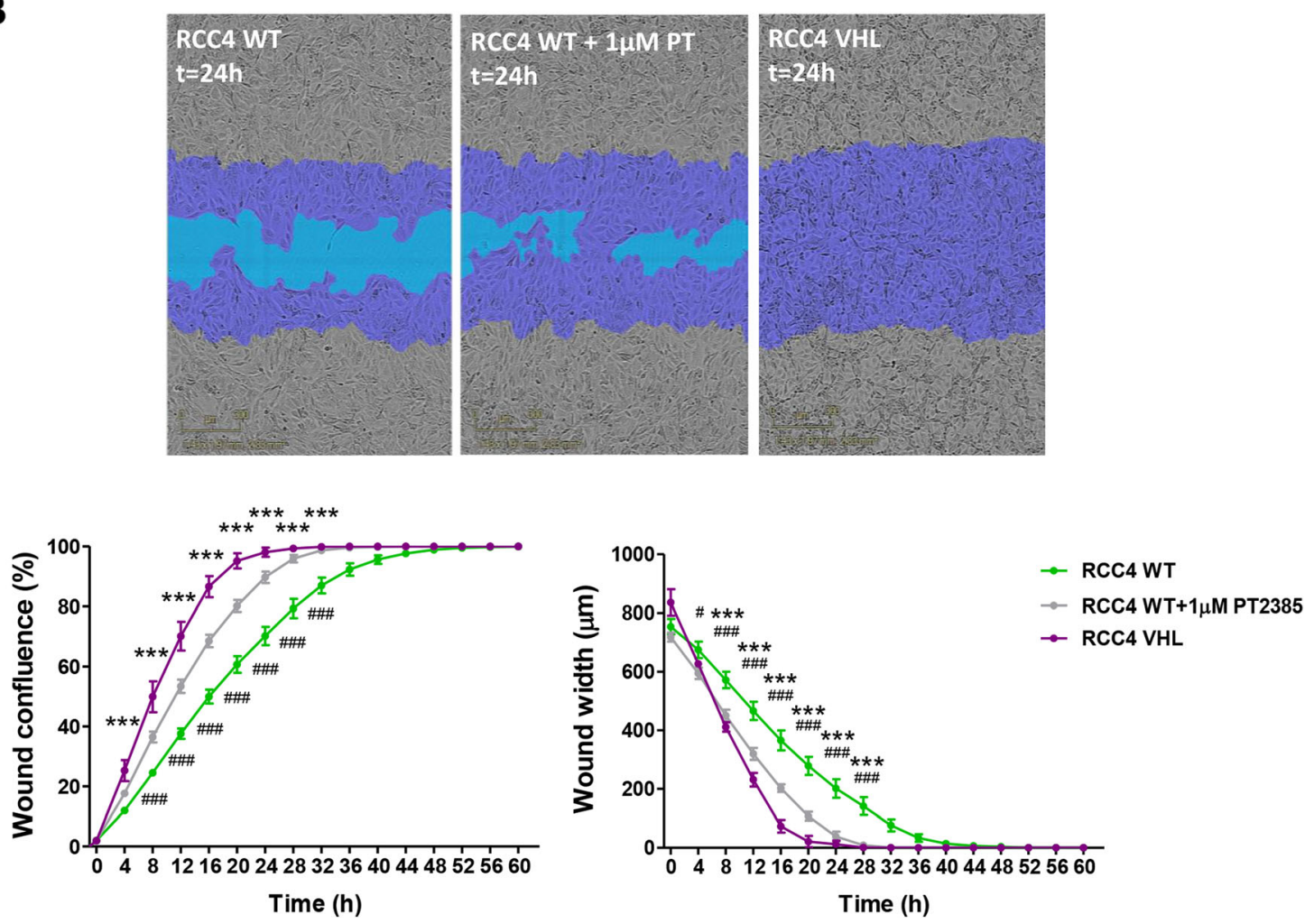

Fig. 1 (See legend on next page.) 
(See figure on previous page.)

Fig. 1 786-0 and RCC4 cell migration. A) Representative images of 786-0 WT and 786-0 WT + 1 HM PT2385 (PT) cells migrating $12 \mathrm{~h}$ after the scratch and wound confluence and wound width measure until the complete closure of the wound. $n=3$. B) Representative images of RCC4 WT, RCC4 WT + $1 \mu \mathrm{M}$ PT2385 (PT) and RCC4 VHL cells migrating $24 \mathrm{~h}$ after the scratch and wound confluence and wound width measure until the complete closure of the wound. $n=3$. * represents comparison between RCC4 WT and RCC4 VHL and \# represents comparison between RCC4 WT and RCC4 WT $+1 \mu \mathrm{M}$ PT2385. Purple region corresponds to the initial scratch mask, whereas blue region represents the wound lacking cells at the compared moment. ${ }^{*} p<0.05,{ }^{* *} p<0.01,{ }^{* *} p<0.001$. Errors bars depict standard error of the mean

WT cells treated with $10 \mu \mathrm{M}$ PT2385 for $48 \mathrm{~h}$ were identified and compared using the $\mathrm{R}$ package -DESeq 2 and ClusterProfiler, respectively. In short, three replicates of the experimental set were compared against three replicates of control set after removal of genes with very low counts.

The top 50 most up-regulated and 50 most downregulated genes upon PT2385 treatment were extracted from the gene expression matrix after removing gene duplicates and used to create the heatmap.

\section{High throughput screening}

300 786-0 WT cells per well were seeded in 384-well plates (GN781090, Sigma) using a Perkin Elmer FlexDrop reagent dispenser the day before treatment. The Pharmakon 1600 library (MicroSource Discovery Systems), including antibacterial, antidiabetic, antifungal, antihypertensive, anti-inflammatory, diuretic, histamine or neurotransmitter-related drugs, among others, was diluted and added to the cells using a Janus automated workstation (PerkinElmer) resulting in final concentrations of $10 \mu \mathrm{M}, 1 \mu \mathrm{M}$ and $0.1 \mu \mathrm{M}$, in duplicate. After a 3day incubation the growth media was replaced with phenol red-free complete media containing $10 \mu \mathrm{g} / \mathrm{mL}$ resazurin. The plates were incubated at $37^{\circ} \mathrm{C}, 5 \% \mathrm{CO}_{2}$ for 2 $\mathrm{h}$ and then fluorescence was read using an Envision plate reader (PerkinElmer). After background subtraction, the data from each plate was normalised by calculating Z-scores. With the exception of a single plate, which was excluded from the analysis due to a plating error, the correlation between the replicates was good, with an average Pearson's coefficient of 0.920 .

\section{Statistical analysis}

GraphPad Prism 5.0 statistical analysis software (GraphPad Software) was used. When analysing the influence of two different independent variables on one dependent variable, 2-way ANOVA with Bonferroni post hoc test was applied. When two means were compared, t-test was performed.

\section{Results}

\section{PT2385 does not inhibit growth of ccRCC cells}

The effect of the HIF $2 \alpha$ analogue PT2385 was assessed in ccRCC cell proliferation and clonogenic survival. PT2385 did not alter 786-0 WT cell proliferation
(Supplementary Figure 1A) nor colony formation (Supplementary Figure 1B). The RCC4 cell line was also analysed. RCC4 VHL cells (reconstituted with non-mutated $V H L)$ generated more colonies than RCC4 WT cells (which express both HIF $1 \alpha$ and HIF $2 \alpha$ ) and addition of PT2385 did not reduce the clonogenic potential of RCC4 WT cells (Supplementary Figure 1C), demonstrating that it does not inhibit in vitro cell growth.

\section{PT2385 treatment promotes tumour cell migration in vitro}

The effect of PT2385 on 786-0 and RCC4 cell migration was analysed using the IncuCyte $\mathrm{ZOOM}^{\circ}$. Whereas PT2385 did not change 786-0 cell migration (Fig. 1A), it promoted the migration of RCC4 WT cells (Fig. 1B). The RCC4 VHL cell line migrated faster than RCC4 WT closing the wound $24 \mathrm{~h}$ after making the scratch compared to the $48 \mathrm{~h}$ needed by RCC4 WT cells (Fig. 1B). Interestingly, PT2385 addition to RCC4 WT cells promoted their migration generating an intermediate phenotype between RCC4 WT and RCC4 VHL cells (Fig. 1B). This suggests that in the RCC4 cell line, not only HIF $2 \alpha$ but also HIF $1 \alpha$ is repressing cell migration.

\section{HIF2a inhibition suppresses cell invasion in vitro}

The invasion ability of these cell lines was also evaluated using the IncuCyte $\mathrm{ZOOM}^{\circ}$. Addition of PT2385 impeded invasion of 786-0 WT cells in a concentrationdependent manner (Fig. 2A). Conversely, neither RCC4 WT nor RCC4 VHL cells were able to invade through the Matrigel $^{\circledR}$, and PT2385 treatment did not have any effect (Fig. 2B).

HIF2 $a$ silencing does not affect cell migration or invasion 786-0 WT cells were transfected with either siCON or siHIF $2 \alpha$ and their migratory and invasion potential was analysed. Similarly to HIF $2 \alpha$ inhibition using PT2385, suppression of HIF $2 \alpha$ with siRNA did not alter the migratory ability of 786-0 WT cells (Supplementary Figure $2 \mathrm{~A})$, but in contrast to the inhibitor, HIF $2 \alpha$ silencing did not reduce their invasion potential (Supplementary Figure $2 \mathrm{~A}$ ). To exclude a possible residual HIF2 $\alpha$ effect in the observed phenotype of 786-0 WT siHIF2 $\alpha$ cells, HIF $2 \alpha$ protein levels and expression of HIF $2 \alpha$ target genes was analysed every $24 \mathrm{~h}$ until the end of the experiment. HIF $2 \alpha$ was not induced over time 


\section{A}
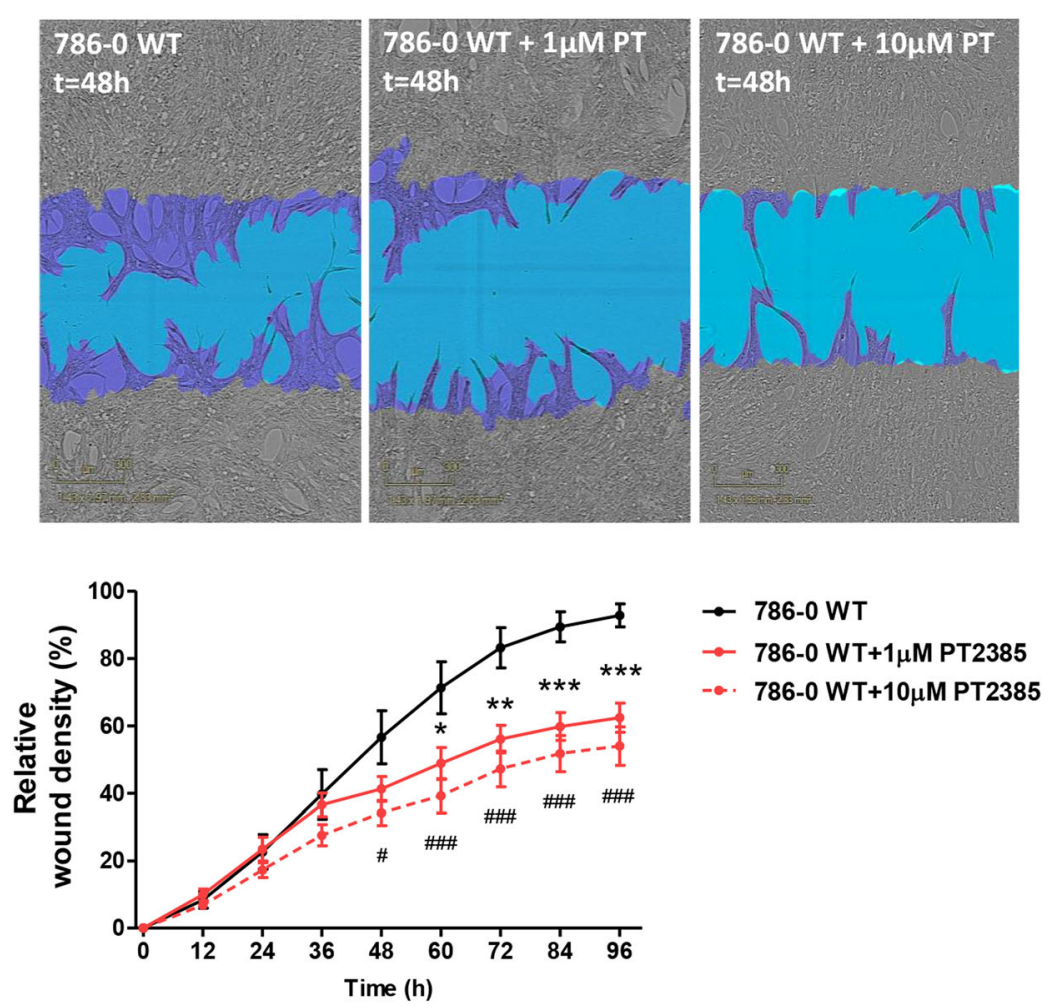

B
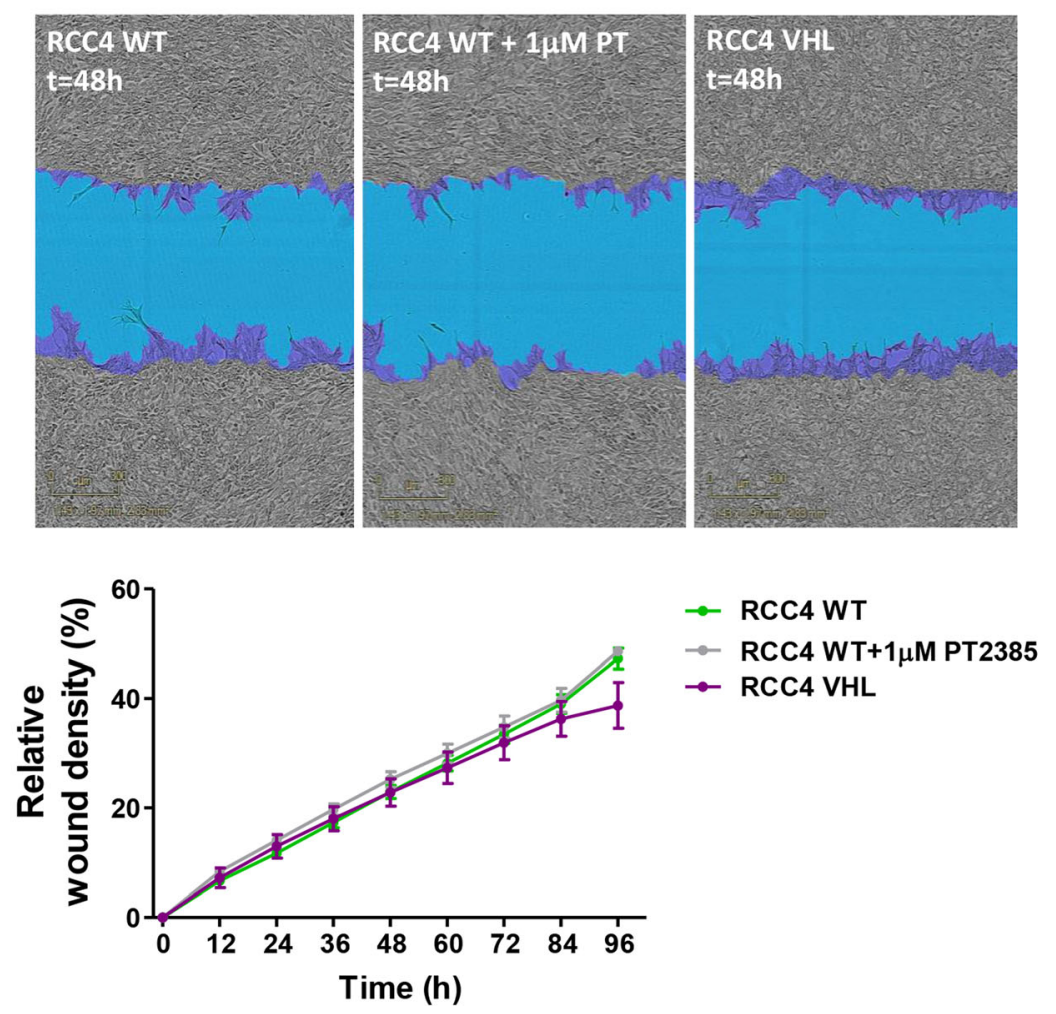

Fig. 2 (See legend on next page.) 
(See figure on previous page.)

Fig. 2 786-0 and RCC4 cell invasion. A) Representative images of 786-0 WT and 786-0 WT + 1/10 $\mu \mathrm{M}$ PT2385 (PT) cells invading 48 h after the scratch and RWD measurement until $96 \mathrm{~h}$ after wound performing. $\mathrm{n}=3$. * represents comparison between 786-0 WT and 786-0 WT $+1 \mu \mathrm{M}$ PT2385 and \# represents comparison between 786-0 WT and 786-0 WT + $10 \mu \mathrm{M}$ PT2385. B) Representative images of RCC4 WT, RCC4 WT + $1 \mu \mathrm{M}$ PT2385 (PT) and RCC4 VHL cells invading the wound $48 \mathrm{~h}$ after the scratch and RWD measurement until $96 \mathrm{~h}$ after wound performing. Purple region corresponds to the initial scratch mask, whereas blue region represents the wound lacking cells at the compared $m o m e n t . n=3 .{ }^{*} p<$ $0.05,{ }^{* *} p<0.01,{ }^{* * *} p<0.001$. Errors bars depict standard error of the mean

(Supplementary Figure 2B), and its downstream targets GLUT1 and VEGFA were not consequently up-regulated (Supplementary Figure 2C).

\section{RNAseq comparison of the parental cell line with PT2385 effects}

RNAseq showed that the most differentially expressed genes upon PT2385 treatment were related to renal development and hypoxia biological processes, followed by GO terms involved in cell migration, such as actin filament organization, tissue migration or regulation of cytoskeleton organization (Supplementary Figure 3A). Supporting the enriched GO terms for biological processes, enriched GO terms for cellular components were related to cell migration/invasion and cell-cell or cellextracellular matrix interaction (ECM) (Supplementary Figure 3B).

Additionally, RNAseq analysis showed an expected down-regulation of many well documented HIF-induced genes upon PT2385 treatment (e.g. NDRG1, SLC2A1, EGLN3 or ROR2) but several other genes were upregulated (Fig. 3, see Supplementary Table 3 for full names). This last group included genes involved in cell migration and ECM (e.g. RAB6B, FN1, VCAM1 or $C O L 14 A 1)$ and genes of signalling pathways usually deregulated in cancer, such as Notch and Wnt signalling (JAG1 and WNT7B, respectively).

\section{HIF2a confers resistance to statin treatment}

The lack of cell growth inhibition by PT2385 but its effect on tumour cell movement led us to investigate if there were currently used drugs to which ccRCC cells would be sensitised.

The drug screening performed in 786-0 WT cells identified several lethal compounds (Fig. 4A). Taking into account previously published data [25], the statins simvastatin and fluvastatin were further analysed, as well as the squalene monooxygenase inhibitor terbinafine, which blocks cholesterol synthesis while allowing the synthesis of non-sterol isoprenoids. We showed that the resistance of 786-0 WT cells to statins was due to HIF2 $\alpha$ expression, as silencing HIF $2 \alpha$ made the cells more sensitive (Fig. 4B). Supporting the no effect on viability, addition of the HIF $2 \alpha$ antagonist did not contribute further to the antiproliferative effects of statins on 786-0 WT cells. However, HIF2 $\alpha$-expressing cells appeared to be more sensitive to terbinafine (Fig. 4B), and as for the statins, addition of PT2385 did not have any additional effect.

Table 2 Results summary

\begin{tabular}{|c|c|c|c|}
\hline Assay & Cell line & Genetic modification / Treatment & Results compared to control \\
\hline Proliferation & 786-0 WT & PT2385 & $=$ \\
\hline \multirow[t]{3}{*}{ Clonogenic assay } & 786-0 WT & PT2385 & $=$ \\
\hline & RCC4 VHL & VHL overexpression & + \\
\hline & RCC4 WT & РT2385 & $=$ \\
\hline \multirow[t]{4}{*}{ Migration } & 786-0 WT & PT2385 & $=$ \\
\hline & 786-0 WT & siHIF2a & $=$ \\
\hline & $\mathrm{RCC} 4 \mathrm{WT}$ & PT2385 & + \\
\hline & RCC4 VHL & VHL overexpression & + \\
\hline \multirow[t]{3}{*}{ Invasion } & 786-0 WT & PT2385 & - \\
\hline & RCC4 VHL & VHL overexpression & $=$ \\
\hline & RCC4 WT & PT2385 & $=$ \\
\hline Sensitivity to statins & 786-0 WT & siHIF2a & + \\
\hline Sensitivity to terbinafine & 786-0 WT & siHIF2a & - \\
\hline
\end{tabular}




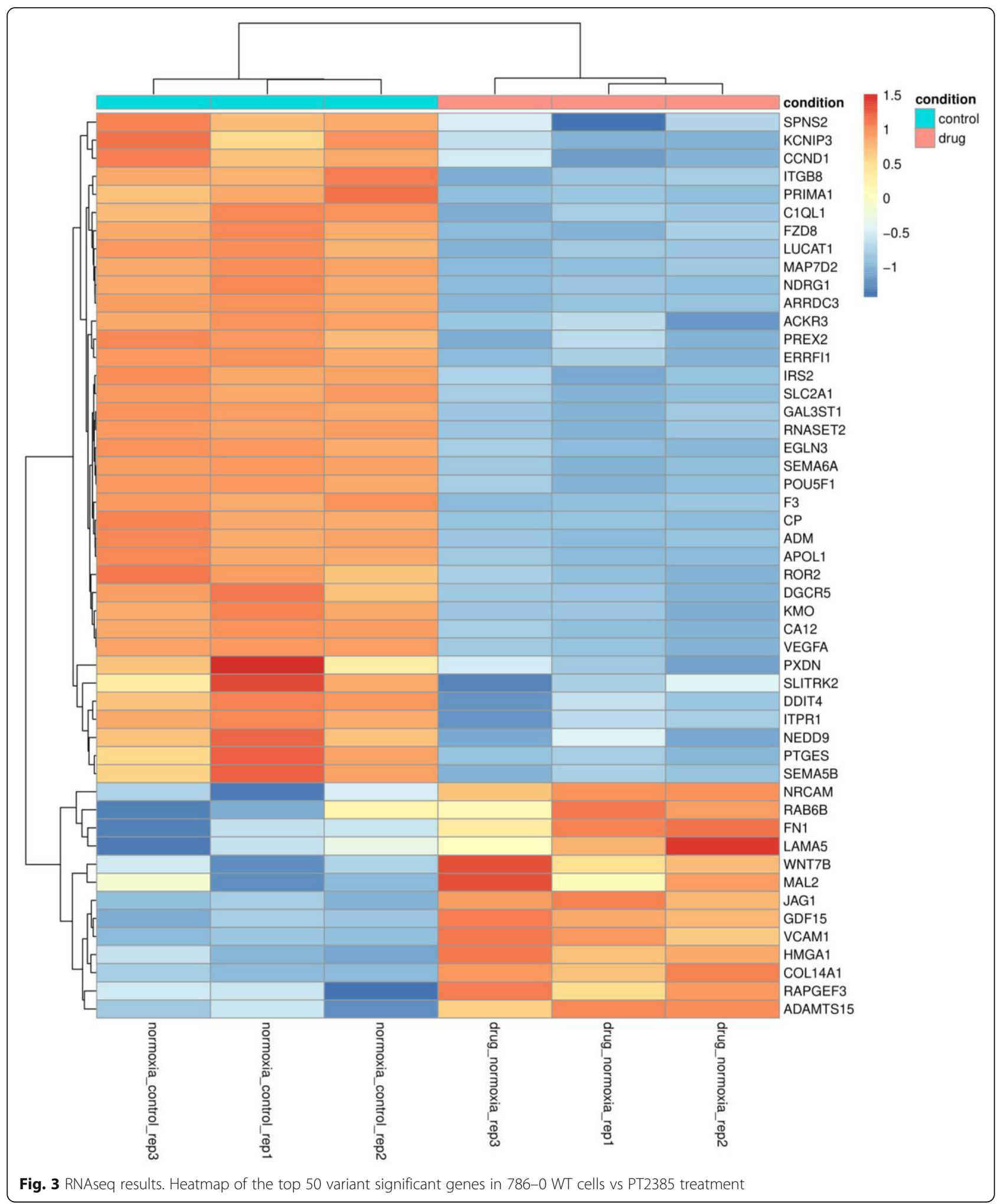

\section{Discussion}

Metastasis is a multistep process which selects for highly aggressive tumour cells, as they acquire the ability to disseminate from the primary tumour and grow at distant sites [29]. Here, we show that the oncoprotein HIF $2 \alpha$ is involved in in vitro cell migration and invasion in ccRCC (Table 2), as has already been described for many tumour cell lines [30-32]. 


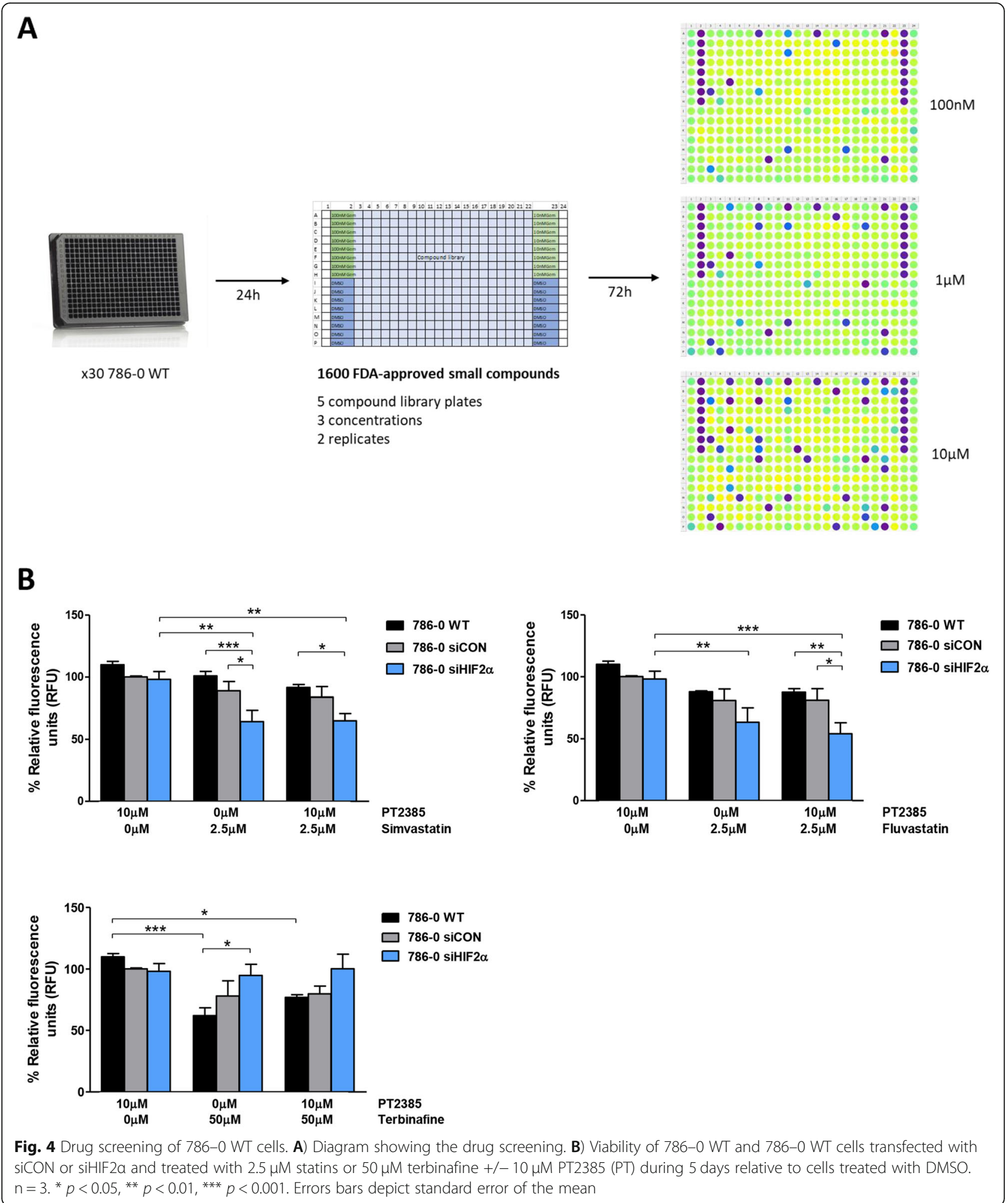

As previously reported [19], the HIF2 $\alpha$ antagonist PT2385 did not affect ccRCC cell proliferation nor colony formation. Interestingly, HIF2 $\alpha$ blockage by PT2385 or siRNA had opposing effects. Treatment with PT2385 did not affect 786-0 cell migration, while partially abolishing cell invasion in a concentration-dependent manner. However, silencing of HIF $2 \alpha$ by siRNA did not change the migration or invasion ability of $786-0$ cells. 
PT2385 allosterically binds to HIF2 $\alpha$ and thereby prevents the heterodimerization with HIF1 $\beta$ and its subsequent binding to the DNA [33], whereas siRNA binds to complementary mRNA and targets them for degradation in a transitory manner [34]. HIF2 $\alpha$ silencing was successfully achieved during the invasion experiment but at the endpoint ( $96 \mathrm{~h}$ ), HIF2 $\alpha$ started to re-express. These results suggest that the few molecules escaping siRNA silencing might be interacting with other molecules, e.g. the MYC/MAX complex [6, 7], to keep the phenotype, even though they are not detectable at protein level. On the other hand, PT2385 treatment showed that DNA binding is not completely abolished by the inhibitor, as previously reported [24], as cell invasion was not 100\% suppressed.

Supporting the role of HIF2 $\alpha$ in the regulation of ccRCC migration, RCC4 VHL cells migrated more than RCC4 WT, in contrast to previous publications [35, 36]. In this case, as RCC4 WT cells also express HIF1 $\alpha$, both HIF $2 \alpha$ and HIF1 $\alpha$ could be inhibiting cell migration; however, treatment with PT2385 generated an intermediate phenotype pointing to a more important role of HIF2 $\alpha$.

RNAseq results showed the already known specificity of PT2385 for HIF2 $\alpha$. PT2385 treatment down-regulated the expression of genes involved in hypoxic response (EGLN3 or CA12), migration (SEMA6A/5B) and metastasis (ITGB8 or VEGFA). These results support the previously described effect of PT2385 avoiding ccRCC tumour progression and metastasis [19]. On the other hand, PT2385 treatment increased the expression of genes involved in cell-cell or cell-ECM interaction, such as FN1, VCAM1, COL14A1 or ADAMTS15. High abundance of components of the ECM like fibronectin 1 or collagen, provided by $\mathrm{Matrigel}^{\circ}$ in our experiments, can possibly explain the inhibition of PT2385 in cell invasion, as the cells might not be able to degrade the ECM and move through it. In addition, high levels of cell-cell adhesion molecules such as VCAM1 could also reduce cell movement.

However, the increased expression of genes upon PT2385 treatment suggests that one way of enhancing the effect of PT2385 could be via combination therapy targeting those molecules. Fibronectin, for instance, exists in multiple isoforms and in adulthood the expression of EDA and EDB domains is very restricted in normal tissue, whereas it is highly expressed in tumours [37]. This has led to the development of drugs or antibodies against these domains as a mechanism of delivering drugs to the tumour site [38, 39]. Treatment of PT2385 increases FN1 expression, increasing the amount of target fibronectin in the tumour and possibly making it easier to specifically deliver tumour-directed drugs. In addition, PT2385 treatment increased the expression of
JAG1 in 786-0 WT cells, suggesting that combining Notch signalling inhibitors already used in clinic with PT2385 could be of benefit for renal cancer treatment. Bhagat et al. (2016) found that genetic and epigenetic alterations in ccRCC tissues led to both Notch ligand and receptor overexpression [40]. JAG1, for instance, was overexpressed and associated with loss of CpG methylation of HeK4me1-associated enhancer regions. They confirmed the procarcinogenic role of Notch in vivo, as previously reported [41], and showed that treatment with the gamma-secretase inhibitor LY3039478 avoided ccRCC cell growth both in vitro and in vivo.

Previous reports demonstrated that HIF2 $\alpha$ silencing does not affect in vitro ccRCC growth under standard culture conditions $[4,42]$. Similarly, we showed that addition of PT2385 did not inhibit tumour cell proliferation or colony formation at concentrations up to $10 \mu \mathrm{M}$, and its combination with statins did not further contribute to the antiproliferative effects of statins. Both the synthetic statin fluvastatin and the semi-synthetic statin simvastatin impaired proliferation in HIF $2 \alpha$ knockdown cells.

Another approach for developing new therapy options in combination with PT2385 would be to identify target genes with synthetic lethal relationship with HIF2 $\alpha$ silencing. Nicholson et al. identified CDK4 and CDK6 as genes with lethal relationship with $V H L$ loss, as loss of either gene alone was well tolerated, but the concurrent loss of both was lethal [43]. Supporting our results, they found that both simvastatin and fluvastatin inhibited the growth of VHL-reconstituted 786-0 cells more substantially than their VHL-defective counterparts. However, in contrast to a previous study [25], our results showed that statin-induced lethality is not due to $V H L$ loss and the consequent HIFs expression, but associated with HIF $2 \alpha$ loss. Thus HIF $2 \alpha$-conferred protection against statins suggests that one way of repurposing these drugs could be via combination treatment with HIF $2 \alpha$ antagonists. Although we were not able to detect differences in cell proliferation in vitro, previously published data on HIF2 $\alpha$ antagonists showed in vivo effects $[19,20]$. However, we are in agreement with Thompson et al. [25] suggesting that the key branch for the observed phenotype is the blockage of isoprenylation and not the cholesterol synthesis pathway, as the lethal effect could not be rescued after treatment with squalene [25] and 786-0 siHIF2 $\alpha$ cells were not sensitive to terbinafine.

\section{Conclusions}

Our study shows new therapy avenues to build on PT2385, as some of the genes that are up-regulated by HIF $2 \alpha$ inhibition, are potential targets for combination treatments. 


\section{Abbreviations}

ATCC: American Type Culture Collection; RCC: Renal cell carcinoma: ccRCC: Clear cell renal cell carcinoma; VHL: Von Hippel-Lindau; HIF1a: Hypoxia-inducible factor 1 alpha; HIF2a: Hypoxia-inducible factor 2 alpha; ECM: Extracellular matrix; EMT: Epithelial to mesenchymal transition; HMG-CoA: 3-hydroxy-3-methyl-glutaryl-coenzyme A; HMGR: HMG-CoA reductase; RWD: Relative wound density; padj: adjusted $p$-value; RNA sequencing: RNAseq

\section{Supplementary Information}

The online version contains supplementary material available at https://doi. org/10.1186/s12885-021-08616-8.

\section{Additional file 1. \\ Additional file 2. \\ Additional file 3. \\ Additional file 4. \\ Additional file 5.}

\section{Acknowledgements}

Not applicable.

\section{Authors' contributions}

E.A., A.M. and A.L.H. designed the experiments and wrote the manuscript. E.A. performed the experiments and analysed the data. N.P. analysed the RNAseq experiments. S.B.H. analysed the drug screening. D.E. designed the drug screening and reviewed the manuscript. C.H.L. and E.B. reviewed the manuscript. The authors (E.A., A.M., E.B., N.P., S.B.H., D.E., C.H.L. and A.L.H.) read and approved the final manuscript.

\section{Authors' information}

EA's present address: Cambridge Institute for Therapeutic Immunology \& Infectious Disease, Jeffrey Cheah Biomedical Centre, Puddlecombe Way, Cambridge, CB2 OAW, UK.

EB's present address: Nuffield Department of Medicine, Weatherall Institute of Molecular Medicine, University of Oxford, John Radcliffe Hospital, Oxford, OX3 9DS, UK.

CHL's additional affiliations: 1) Radcliffe Department of Medicine, University of Oxford, John Radcliffe Hospital, Oxford, OX3 9DU, UK, 2) IKERBASQUE, Basque Foundation for Science, María Díaz Haroko Kalea 3, Bilbao, 48013, Spain.

\section{Funding}

This work was supported by funding from Cancer Research UK and the Basque Country Government (PRE_2018_2_0018).

\section{Availability of data and materials}

The RNAseq data generated and analysed during the current study is available in the NCBI's Gene Expression Omnibus repository, and is accessible through GEO Series accession number GSE153711 (https://www.ncbi.nlm.nih. gov/geo/query/acc.cgi?acc=GSE153711).

\section{Declarations}

Ethics approval and consent to participate

Not applicable.

\section{Consent for publication}

Not applicable.

\section{Competing interests}

The authors declare that they have no competing interests.

\section{Author details}

'Department of Medical Oncology, Molecular Oncology Laboratories, Weatherall Institute of Molecular Medicine, University of Oxford, John Radcliffe Hospital, Oxford OX3 9DS, UK. ${ }^{2}$ Department of Oncology, Old Road Campus Research Building, University of Oxford, Oxford OX3 7DQ, UK.
${ }^{3}$ Nuffield Department of Medicine, NDM Research Building, University of Oxford, Oxford OX3 7DQ, UK. ${ }^{4}$ Department of Oncology, Molecular Oncology Group, Biodonostia Health Research Institute, Paseo Doctor Begiristain s/n, 20014 San-Sebastián, Spain.

Received: 12 February 2021 Accepted: 15 July 2021

Published online: 05 August 2021

References

1. Capitanio U, Bensalah K, Bex A, Boorjian SA, Bray F, Coleman J, et al. Epidemiology of renal cell carcinoma. Eur Urol. 2019;75(1):74-84. https://doi. org/10.1016/j.eururo.2018.08.036.

2. Wettersten HI, Aboud OA, Lara PN Jr, Weiss RH. Metabolic reprogramming in clear cell renal cell carcinoma. Nat Rev Nephrol. 2017;13(7):410-9. https:// doi.org/10.1038/nrneph.2017.59.

3. Huang LE, Gu J, Schau M, Bunn HF. Regulation of hypoxia-inducible factor 1alpha is mediated by an O2-dependent degradation domain via the ubiquitin-proteasome pathway. Proc Natl Acad Sci U S A. 1998;95(14):798792. https://doi.org/10.1073/pnas.95.14.7987.

4. Raval RR, Lau KW, Tran MG, Sowter HM, Mandriota SJ, Li JL, et al. Contrasting properties of hypoxia-inducible factor 1 (HIF-1) and HIF-2 in von Hippel-Lindau-associated renal cell carcinoma. Mol Cell Biol. 2005;25(13): 5675-86. https://doi.org/10.1128/MCB.25.13.5675-5686.2005.

5. Gordan JD, Lal P, Dondeti VR, Letrero R, Parekh KN, Oquendo CE, et al. HIFalpha effects on c-Myc distinguish two subtypes of sporadic VHL-deficient clear cell renal carcinoma. Cancer Cell. 2008:14(6):435-46. https://doi.org/1 0.1016/j.ccr.2008.10.016.

6. Gordan JD, Bertout JA, Hu CJ, Diehl JA, Simon MC. HIF-2alpha promotes hypoxic cell proliferation by enhancing c-myc transcriptional activity. Cancer Cell. 2007;11(4):335-47. https://doi.org/10.1016/j.ccr.2007.02.006.

7. Poole CJ, van Riggelen J. MYC-master regulator of the Cancer epigenome and transcriptome. Genes (Basel). 2017;8(5):142. https://doi.org/10.3390/ genes8050142.

8. Rey S, Semenza GL. Hypoxia-inducible factor-1-dependent mechanisms of vascularization and vascular remodelling. Cardiovasc Res. 2010;86(2):236-42. https://doi.org/10.1093/cvr/cvq045.

9. Gilkes DM, Semenza GL. Role of hypoxia-inducible factors in breast cancer metastasis. Future oncology (London, England). 2013;9(11):1623-36.

10. Schito L, Rey S, Tafani M, Zhang H, Wong CC, Russo A, et al. Hypoxiainducible factor 1-dependent expression of platelet-derived growth factor $\mathrm{B}$ promotes lymphatic metastasis of hypoxic breast cancer cells. Proc Natl Acad Sci U S A. 2012;109(40):E2707-16. https://doi.org/10.1073/pnas.121401 9109.

11. Vanharanta S, Shu W, Brenet F, Hakimi AA, Heguy A, Viale A, et al. Epigenetic expansion of VHL-HIF signal output drives multiorgan metastasis in renal cancer. Nat Med. 2013;19(1):50-6. https://doi.org/10.1038/nm.3029.

12. Nishida J, Momoi Y, Miyakuni K, Tamura Y, Takahashi K, Koinuma D, et al. Epigenetic remodelling shapes inflammatory renal cancer and neutrophildependent metastasis. Nat Cell Biol. 2020;22(4):465-75. https://doi.org/10.1 038/s41556-020-0491-2.

13. Rankin EB, Fuh KC, Castellini L, Viswanathan K, Finger EC, Diep AN, et al. Direct regulation of GAS6/AXL signaling by HIF promotes renal metastasis through SRC and MET. Proc Natl Acad Sci U S A. 2014;111(37):13373-8. https://doi.org/10.1073/pnas.1404848111.

14. Rodrigues P, Patel SA, Harewood L, Olan I, Vojtasova E, Syafruddin SE, et al. NF-kappaB-dependent lymphoid enhancer co-option promotes renal carcinoma metastasis. Cancer Discover. 2018;8(7):850-65. https://doi.org/1 0.1158/2159-8290.CD-17-1211.

15. Wierzbicki PM, Klacz J, Kotulak-Chrzaszcz A, Wronska A, Stanislawowski M, Rybarczyk A, et al. Prognostic significance of VHL, HIF1A, HIF2A, VEGFA and p53 expression in patients with clearcell renal cell carcinoma treated with sunitinib as firstline treatment. Int J Oncol. 2019;55(2):371-90. https://doi. org/10.3892/ijo.2019.4830.

16. Key J, Scheuermann TH, Anderson PC, Daggett V, Gardner KH. Principles of ligand binding within a completely buried cavity in HIF2alpha PAS-B. J Am Chem Soc. 2009;131(48):17647-54. https://doi.org/10.1021/ja9073062.

17. Rogers JL, Bayeh L, Scheuermann TH, Longgood J, Key J, Naidoo J, et al. Development of inhibitors of the PAS-B domain of the HIF-2alpha transcription factor. J Med Chem. 2013;56(4):1739-47. https://doi.org/10.1 021/jm301847z 
18. Scheuermann TH, Tomchick DR, Machius M, Guo Y, Bruick RK, Gardner KH. Artificial ligand binding within the HIF2alpha PAS-B domain of the HIF2 transcription factor. Proc Natl Acad Sci U S A. 2009;106(2):450-5. https://doi. org/10.1073/pnas.0808092106.

19. Wallace EM, Rizzi JP, Han G, Wehn PM, Cao Z, Du X, et al. A small-molecule antagonist of HIF2alpha is efficacious in preclinical models of renal cell carcinoma. Cancer Res. 2016;76(18):5491-500. https://doi.org/10.1158/00085472.CAN-16-0473.

20. Chen W, Hill H, Christie A, Kim MS, Holloman E, Pavia-Jimenez A, et al. Targeting renal cell carcinoma with a HIF-2 antagonist. Nature. 2016; 539(7627):112-7. https://doi.org/10.1038/nature19796.

21. Cho H, Kaelin WG. Targeting HIF2 in clear cell renal cell carcinoma. Cold Spring Harb Symp Quant Biol. 2016;81:113-21. https://doi.org/10.1101/sqb.2 016.81.030833.

22. Courtney KD, Infante JR, Lam ET, Figlin RA, Rini BI, Brugarolas J, et al. Phase I dose-escalation trial of PT2385, a first-in-class hypoxia-inducible factor-2a antagonist in patients with previously treated advanced clear cell renal cell carcinoma. J Clin Oncol. 2018;36(9):867-74. https://doi.org/10.1200/JCO.201 7.74.2627.

23. Xu R, Wang K, Rizzi JP, Huang H, Grina JA, Schlachter ST, et al. 3-[(1S,2S,3R)2,3-Difluoro-1-hydroxy-7-methylsulfonylindan-4-yl]oxy-5-fluorobenzo nitrile (PT2977), a hypoxia-inducible factor 2alpha (HIF-2alpha) inhibitor for the treatment of clear cell renal cell carcinoma. J Med Chem. 2019;62(15):687693. https://doi.org/10.1021/acs.jmedchem.9b00719.

24. Wu D, Su X, Lu J, Li S, Hood BL, Vasile S, et al. Bidirectional modulation of HIF-2 activity through chemical ligands. Nat Chem Biol. 2019;15(4):367-76. https://doi.org/10.1038/s41589-019-0234-5.

25. Thompson JM, Alvarez A, Singha MK, Pavesic MW, Nguyen QH, Nelson LJ, et al. Targeting the mevalonate pathway suppresses VHL-deficient CC-RCC through an HIF-dependent mechanism. Mol Cancer Ther. 2018;17(8):178192. https://doi.org/10.1158/1535-7163.MCT-17-1076.

26. Shepherd J, Cobbe SM, Ford I, Isles CG, Lorimer AR, MacFarlane PW, et al. Prevention of coronary heart disease with pravastatin in men with hypercholesterolemia. 1995. Atheroscler Suppl. 2004;5(3):91-7. https://doi. org/10.1016/j.atherosclerosissup.2004.08.029.

27. Iliopoulos O, Kibel A, Gray S, Kaelin WG Jr. Tumour suppression by the human von Hippel-Lindau gene product. Nat Med. 1995;1(8):822-6. https:// doi.org/10.1038/nm0895-822.

28. Miar A, Arnaiz E, Bridges E, Beedie S, Cribbs AP, Downes DJ, et al. Hypoxia induces transcriptional and translational downregulation of the type I interferon (IFN) pathway in multiple cancer cell types. Cancer Research. 2020;80(23):5245-56. https://doi.org/10.1158/0008-5472.CAN-19-2306.

29. Rankin EB, Giaccia AJ. Hypoxic control of metastasis. Science (New York, NY). 2016;352(6282):175-80.

30. Wang Y, Li Z, Zhang H, Jin H, Sun L, Dong H, et al. HIF-1alpha and HIF2alpha correlate with migration and invasion in gastric cancer. Cancer Biol Ther. 2010;10(4):376-82. https://doi.org/10.4161/cbt.10.4.12441.

31. Wang $X$, Schneider A. HIF-2alpha-mediated activation of the epidermal growth factor receptor potentiates head and neck cancer cell migration in response to hypoxia. Carcinogenesis. 2010;31(7):1202-10. https://doi.org/1 0.1093/carcin/bgq078.

32. Torres A, Erices Jl, Sanchez F, Ehrenfeld P, Turchi L, Virolle T, et al. Extracellular adenosine promotes cell migration/invasion of glioblastoma stem-like cells through A3 adenosine receptor activation under hypoxia. Cancer Lett. 2019;446:112-22. https://doi.org/10.1016/j.canlet.2019.01.004.

33. Scheuermann TH, Li Q, Ma HW, Key J, Zhang L, Chen R, et al. Allosteric inhibition of hypoxia inducible factor-2 with small molecules. Nat Chem Biol. 2013;9(4):271-6. https://doi.org/10.1038/nchembio.1185.

34. Dana H, Chalbatani GM, Mahmoodzadeh H, Karimloo R, Rezaiean O, Moradzadeh A, et al. Molecular mechanisms and biological functions of siRNA. Int J Biomed Sci. 2017;13(2):48-57.

35. Hu H, Takano N, Xiang L, Gilkes DM, Luo W, Semenza GL. Hypoxia-inducible factors enhance glutamate signaling in cancer cells. Oncotarget. 2014;5(19): 8853-68. https://doi.org/10.18632/oncotarget.2593.

36. Sumi C, Matsuo Y, Kusunoki M, Shoji T, Uba T, Iwai T, et al. Cancerous phenotypes associated with hypoxia-inducible factors are not influenced by the volatile anesthetic isoflurane in renal cell carcinoma. PLoS One. 2019; 14(4):e0215072. https://doi.org/10.1371/journal.pone.0215072.

37. Kumra $H$, Reinhardt DP. Fibronectin-targeted drug delivery in cancer. Adv Drug Deliv Rev. 2016:97:101-10. https://doi.org/10.1016/j.addr.2015.11.014.
38. Frey K, Schliemann C, Schwager K, Giavazzi R, Johannsen M, Neri D. The Immunocytokine F8-IL2 improves the therapeutic performance of Sunitinib in a mouse model of renal cell carcinoma. J Urol. 2010;184(6):2540-8. https://doi.org/10.1016/j.juro.2010.07.030.

39. Johannsen M, Spitaleri G, Curigliano G, Roigas J, Weikert S, Kempkensteffen C, et al. The tumour-targeting human L19-IL2 immunocytokine: preclinical safety studies, phase I clinical trial in patients with solid tumours and expansion into patients with advanced renal cell carcinoma. Eur J Cancer. 2010;46(16):2926-35. https://doi.org/10.1016/j.ejca.2010.07.033.

40. Bhagat TD, Zou Y, Huang S, Park J, Palmer MB, Hu C, et al. Notch pathway is activated via genetic and epigenetic alterations and is a therapeutic target in clear cell renal Cancer. J Biol Chem. 2017;292(3):837-46. https://doi.org/1 0.1074/jbc.M116.745208.

41. Sjölund J, Johansson M, Manna S, Norin C, Pietras A, Beckman S, et al. Suppression of renal cell carcinoma growth by inhibition of notch signaling in vitro and in vivo. J Clin Invest. 2008;118(1):217-28. https://doi.org/10.11 72/JCl32086.

42. Cho H, Du X, Rizzi JP, Liberzon E, Chakraborty AA, Gao W, et al. On-target efficacy of a HIF-2alpha antagonist in preclinical kidney cancer models. Nature. 2016;539(7627):107-11. https://doi.org/10.1038/nature19795.

43. Nicholson HE, Tariq Z, Housden BE, Jennings RB, Stransky LA, Perrimon N, et al. HIF-independent synthetic lethality between CDK4/6 inhibition and VHL loss across species. Sci Signaling. 2019;12(601):eaay0482.

\section{Publisher's Note}

Springer Nature remains neutral with regard to jurisdictional claims in published maps and institutional affiliations.
Ready to submit your research? Choose BMC and benefit from:

- fast, convenient online submission

- thorough peer review by experienced researchers in your field

- rapid publication on acceptance

- support for research data, including large and complex data types

- gold Open Access which fosters wider collaboration and increased citations

- maximum visibility for your research: over $100 \mathrm{M}$ website views per year

At BMC, research is always in progress.

Learn more biomedcentral.com/submissions 